\title{
Design Automation of the Manufacturing Process of a Mini Biodiesel Plant
}

\author{
Deivison Silveira Santos de Jesus \\ SENAI, Camaçari - BA, Brazil \\ FAMEC, Camaçari - BA, Brazil \\ CETEB/CA BRA, Camaçari - BA, Brazil
}

\begin{abstract}
The increasing pollution in the atmospheric layer has meant world-wide temperature variations, causing the melting of icecaps and floods, among other environmental factors. This change in temperature has been mainly caused by the indiscriminate emission of $\mathrm{CO}_{2}$, especially due to the rising number of vehicles in circulation. Researchers have identified that, among other types of fuel, diesel has the highest level of $\mathrm{CO}_{2}$ emission. Hence the need for the development of biodiesel, produced from oleaginous plants, aimed at reducing the emission of this harmful gas into the atmosphere, besides using renewable resources. However, as in any automation process, it is necessary to have sensors, actuators, and controllers, which together perform the automation and control of the production process. Besides that, there are other process variables to be accounted for, such as temperature, flow, and level. Considering such concept, and within the academic context, the creation process of a mini biodiesel plant will be described.
\end{abstract}

Keywords: biodiesel, mini-plant, automation, control

\section{Introduction}

Environmental degradation is a problem that affects the inhabitants of the whole planet. The average temperature variations of the atmosphere and oceans are a great cause of concern, and one of the main factors responsible is the emission of $\mathrm{CO}_{2}$ by vehicles. Aspects that characterize and justify the present work will be demonstrated, based on the premise that there are various reasons for the interest in biofuel, among which is the reduction of the dependence on petrol and the emission of $\mathrm{CO}_{2}$ into the atmosphere.

The world consumption of energy has practically doubled between 1975 and 2005, rising from six billions Mtoe to almost 12 billions Mtoe (Bueno, Esperancini, \& Takitane, 2009). From this total, almost 87\% refer to non-renewable energy, which represents an unsustainable source of energy in the long run (Ferrés, 2010). The prediction of fuel consumption is essential for companies working in this sector, as it helps logistics, budget and strategic planning, among others (Brafman, 2009).

Leal and Leite (2007) said:

Deivison Silveira Santos de Jesus, Postgraduate Student, Department of Reliability Engineer, SENAI; Automation and Control Engineer, FAMEC; Technician Electronics, CETEB/CA BRA.

Correspondence concerning this article should be addressed to Deivison Silveira Santos de Jesus, 42807-050, N 67 Camaçari BA, Brazil. E-mail: silveirads@yahoo.com.br. 
The search of alternative solutions for the consumption of petrol, since the 70's, and the concern with environmental pollution and the emission of harmful gases to the atmosphere reinforce the importance of commercial production of biodiesel. (p. 1)

As a result of this, the number of publications and patents has increased exponentially throughout the years, as it can be shown in Figure 1.

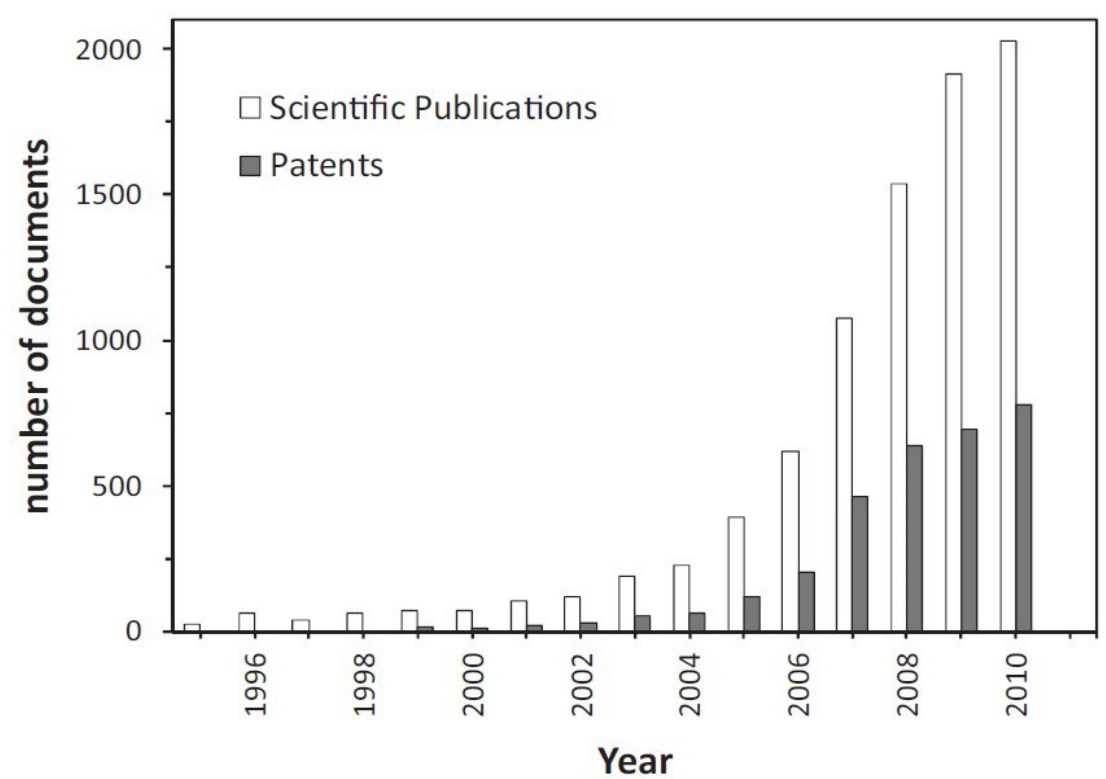

Figure 1. Number of scientific publications and patents regarding biodiesel. Source: Santacesaria, Vicente, Di Serio, and Tesser, 2012.

According to the Law 11.097 of January 2005, biodiesel can be classified as any alternative fuel of renewable nature that can offer socio-environmental advantages when used in total or partial substitution of petrol diesel, in ignition engines of internal combustion.

Therefore, biodiesel can be classified as animal or plant oil-based fuel, extracted mainly from oleaginous plants. Its chemical composition is made of three molecules of unsaturated fatty acids and one molecule of glycerin, as demonstrated in Figure 2.

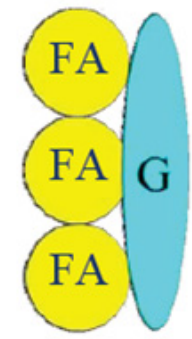

Figure 2. Composition of triglyceride. Source: Atkins \& Jones, 2001.

For Meirelles (2003), biodiesel is the alkyl ester of fatty acids, obtained through the transesterification of any triglyceride (animal or vegetable oil) with short chain alcohol (methanol or ethanol).

Grimoni, Udaeta, Baitelo, and Burani (2006) said that the energy crisis in Brazil has generated discussions regarding the availability of energy resources and energy supply. Energy sources can be classified in conventional and alternative. The conventional sources are characterized by having low cost, however can cause great 
environmental impacts. They are sub-classified into renewable (extracted from natural sources and with lower environmental impact, such as biofuel), and non-renewable (found in nature, but can be extinguished according to its use, such as petrol).

According to Figure 3, in comparison to the world greatest economies USA and Germany, Brazil had a significant increase in the production of biodiesel between January 2009 and January 2011.

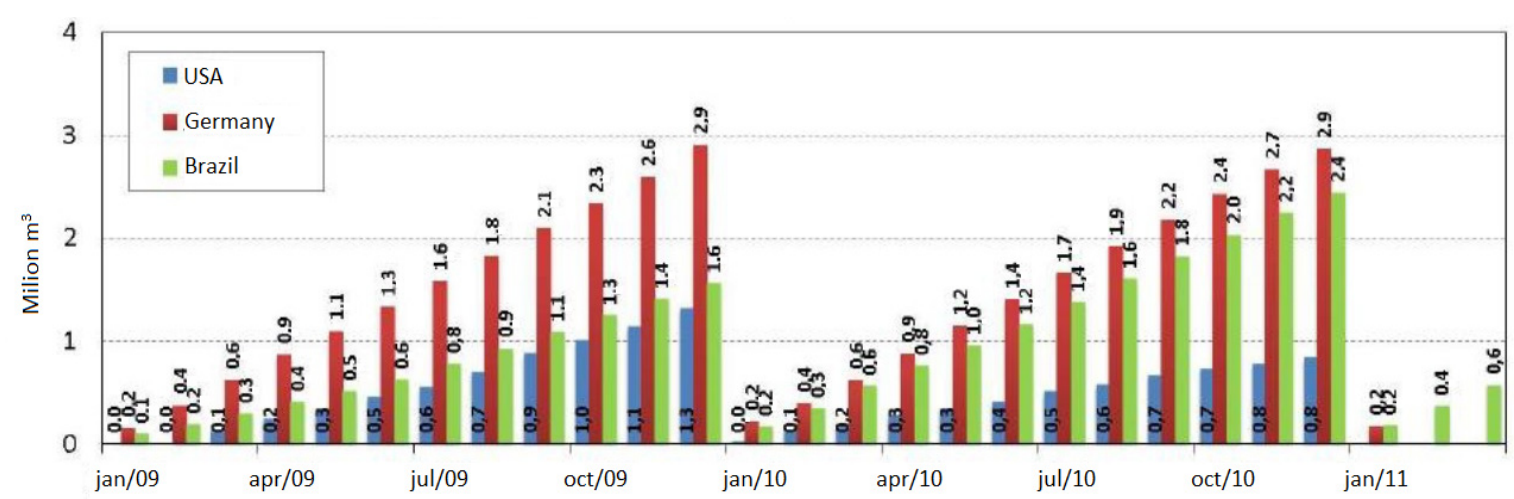

Figure 3. Production of biodiesel in Brazil, USA, and Germany. Source: D'avila, 2011.

Biodiesel is a substitute for diesel, has a cleaner combustion process and is produced from renewable energy sources such as mineral and vegetal oil. It can operate combustion-ignition engines in the same way as mineral diesel.

\section{Biodiesel Production}

The rapid evolution of society and growing technological process has led researchers and scientists to develop alternative sources of energy aimed at decreasing the release of carbon dioxide into the atmosphere.

Rampin, Bronzel, and Dabdoub (2009) said that the increase in the world-wide demand for liquid fuel, the global warming and the political agenda regarding agricultural, social and energy development are all new areas of interest. Ethanol and biodiesel are two examples of this new area of interest, and both are already being produced in Brazil.

According to Schechtman and Pires (2012) Figure 4 represents the growth in the world-wide production of biofuel between 1990 and 2008.

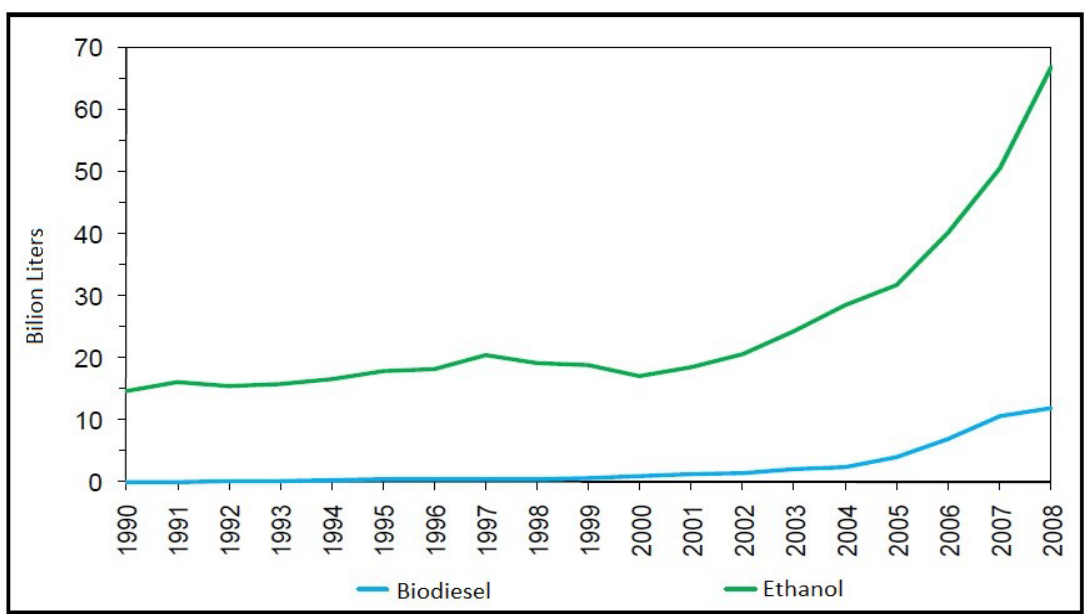

Figure 4. World production of biodiesel. Source: Schechtman and Pires (2012). 
In Belgium, in 1937, the researcher Chavane patented the method of transforming vegetal oil in fatty acid methyl and ethyl esters, to be used as fuel in internal combustion engines ("Procedéemvue de leurutilisationcommecarburants" or method of use as fuel, describing the transesterification of African pal oil).

But biodiesel is not only produced from plants and animals. Studies indicate that oil left over from frying also has a great potential to be transformed. Pétris, Pereira, and Silva (2007) said that an initial survey of residual oils from frying reveals a potential supply in the country superior to 30 thousand tons a year.

Its chemical structures are as shown in Figure 5.

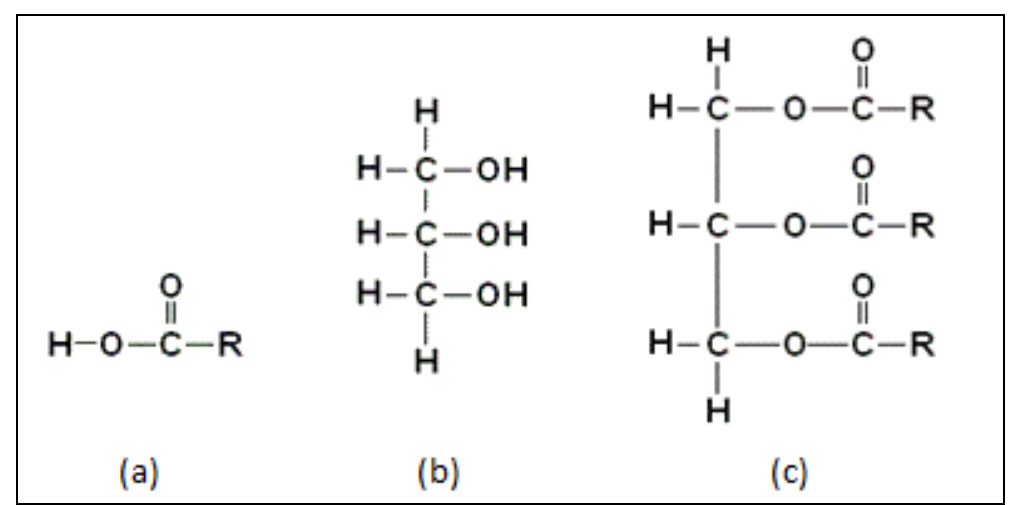

Figure 5. Chemical structure of (a) fatty acids, (b) glycerol, and (c) triglyceride. Source: Atkins \& Jones, 2001.

According to Atkins and Jones (2001), the esters of bigger molecules constitute the oils and fats, both from animal and vegetal origin. Esters of very big molecules appear in vegetable wax and in the organism of animals.

A chemical process called transesterification is necessary before biodiesel can be produced from oleaginous plants.

In the definition of the patent PI 0603857-3A (2008), transesterification is the production of alkyl esters, such as biodiesel, from any vegetable oil or animal fat, in the methylic or ethylic routes, catalyzed by a strong modified base, both in the homogenous phase, where a high yield is obtained, and a transesterification reaction, promoting a spontaneous decantation of glycerin.

Figure 6 expresses, in a simplified way, the process of producing biodiesel.

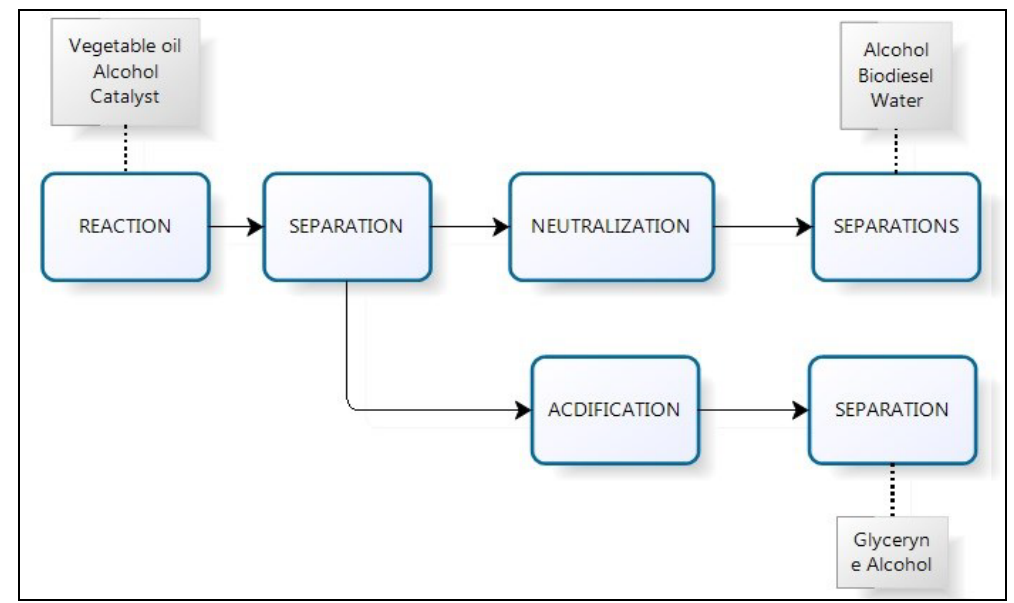

Figure 6. Simplified diagram showing the process of biodiesel production. Source: Santori et al., 2011. 
According to Parente (2003), the process of producing biodiesel occurs as shown in Figure 7.

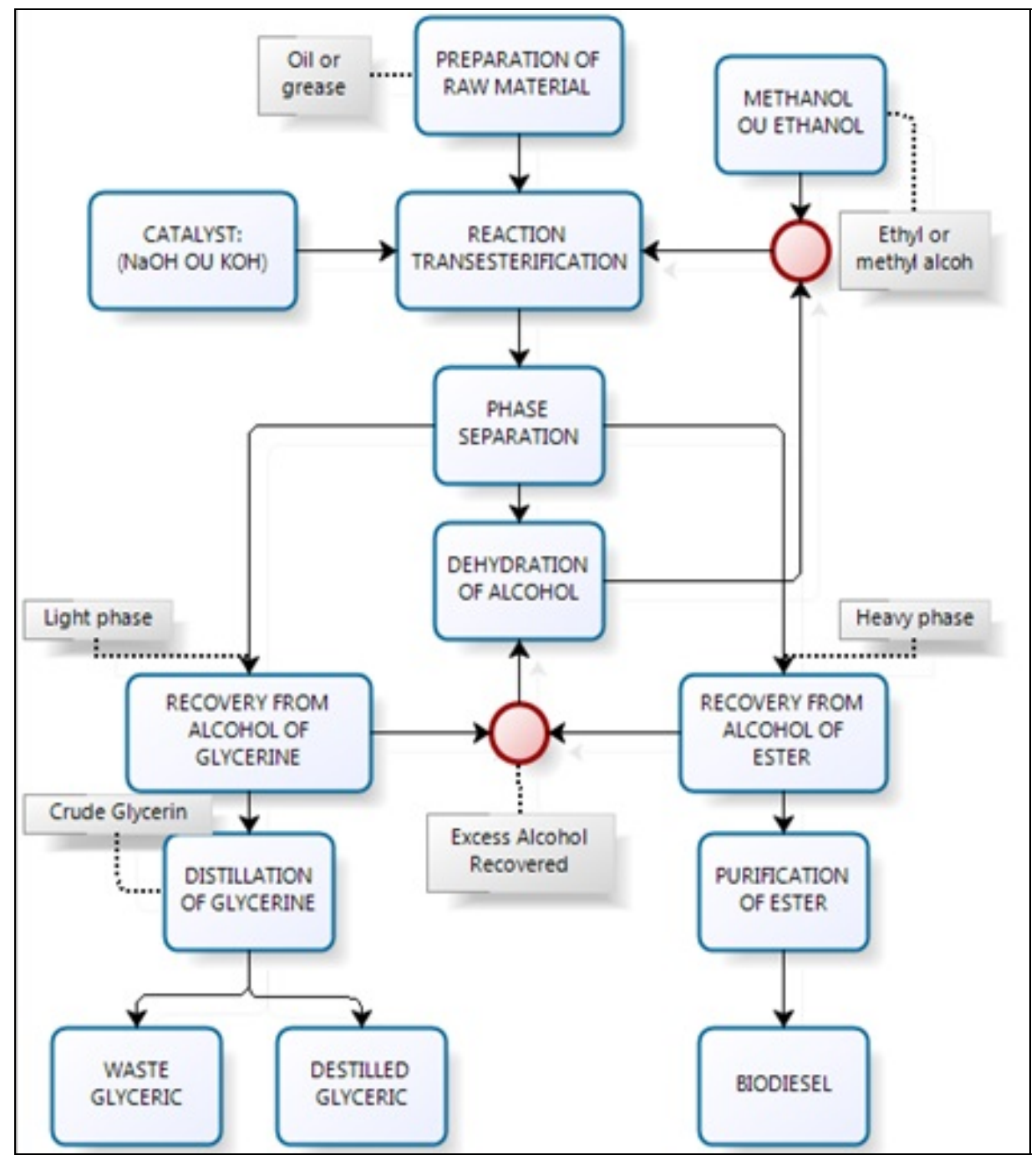

Figure 7. Process of producing biodiesel according to Expedito José de SáParente. Source: Parente, 2003.

\section{Preparation of Raw Material}

Initially, it is necessary that the raw material has a minimum humidity and acidity, which occurs through a process of neutralization. This can be achieved by washing with an alkaline solution of sodium or potassium hydroxide, followed by drying or a dehumidification process. The specificities of the treatment will depend on the nature and conditions of the grease used as raw material (Parente, 2003).

\section{Transesterification Process}

Transesterification is a chemical process of separating the raw material used (oil or grease) into fatty acids ethylic or methylic esters, which constitute the biodiesel. This process has been largely used for reducing the viscosity of triglycerides, improving the physical properties of engines using diesel (Urioste, 2004).

However, for the transesterification to occur, it is necessary to add alcohol. Geris et al. (2007) said that, in the transesterification of vegetal oils, a triacylglycerol reacts with an alcohol in the presence of a strong base or acid, producing a mixture of fatty acids esters and glycerol. 


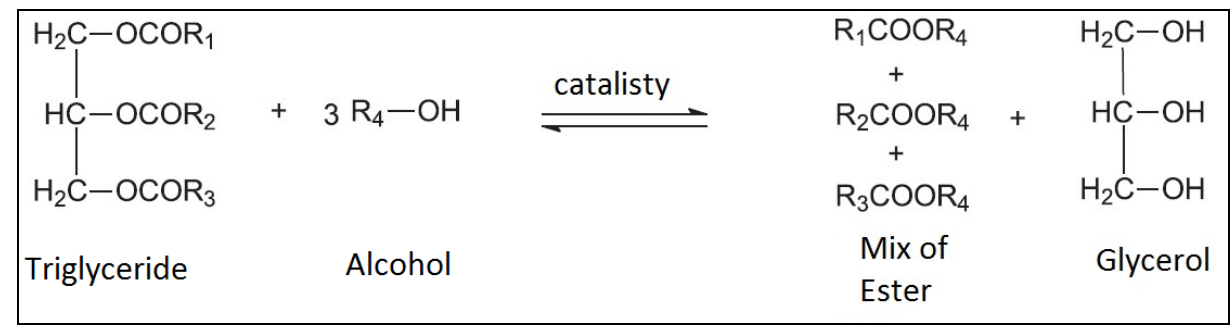

Figure 8. General equation of a transesterification of a triacylglycerol. Source: Geris et al., 2007.

For a complete stoichiometrically transesterification, a molar proportion 3:1 of alcohol per triacylglycerol is needed, as shown in Figure 8. For production, the use of either ethylic or methylic alcohol is necessary. Table 1 shows the comparison of these two types of alcohol.

Table 1

Comparison of the Production Process

\begin{tabular}{lll}
\hline Approximate quantity and average usual measures & Process routes & \\
\cline { 2 - 3 } & Methylic & Ethylic \\
\hline Quantity of alcohol consumed per 1.000 liters of biodiesel & $90 \mathrm{~kg}$ & $130 \mathrm{~kg}$ \\
Average price of alcohol, US $\$ \mathrm{~kg}$ & 190 & 360 \\
Excess of recoverable alcohol recommended, by distillation, after reaction & $100 \%$ & $650 \%$ \\
Recommendedtemperatureofreaction & $60{ }^{\circ} \mathrm{C}$ & $85^{\circ} \mathrm{C}$ \\
Time of reaction & $45 \mathrm{~min}$ & $90 \mathrm{~min}$ \\
\hline
\end{tabular}

Note. Source: Parente, 2003.

According to the National Food Supply Company (CONAB), and as shown in Table 2, ethanol is a biofuel already produced in Brazil and distributed to all regions, facilitating its delivery and reducing costs related to the transportation of alcohol.

Table 2

Production of Ethanol in Brazil

\begin{tabular}{lccc}
\hline \multirow{2}{*}{ Region } & Production & Area & Productivity \\
\cline { 2 - 4 } & Milions of tons & Mil ha & ton/ha \\
\hline North & 1,420 & 21.9 & 64.9 \\
Northeast & 64,619 & 1,133 & 57.1 \\
Central-West & 45,016 & 605 & 74.5 \\
Southeast & 327,843 & 3,941 & 83.2 \\
South & 36,829 & 489 & 75.3 \\
Total & 475,727 & $6,189.9$ & 355 \\
\hline
\end{tabular}

Note. Source: CONAB, 2008.

From an environmental point of view, the use of ethanol has advantages over the use of methanol, since this is obtained from petrol byproducts. However, it is important to consider that methanol can also be produced from biomass, and this supposedly ecological advantage can eventually disappear (Parente, 2003).

\section{Phase Separation}

After transesterification, the matter is constituted of two parts, which, according to Parente (2003), can be separated in two ways: decantation and/or centrifugation. 
Decantation is a mechanical process that serves to unfold heterogeneous mixtures from solid into liquid or from two immiscible liquids (Feltre, 2004).

Centrifugation is also used to accelerate the separation of two phases. The centrifuge provides a fast rotation in the recipient where a solid matter is suspended in a liquid solution. With the rapid acceleration caused by rotation, the solid particles sediment at the bottom of the recipient.

One of these parts is solid and consequently heavier, composed by raw glycerin. The less dense part is constituted of a mixture of methylic or ethylic esters.

\section{Recuperation of Alcohol From Glycerin}

The heavy phase, containing water and alcohol, is submitted to a process of evaporation, eliminating these volatile components from the raw glycerin, whose vapors are liquefied in an appropriate condenser (Parente, 2003).

\section{Recuperation of Alcohol From Esters}

In the same way, but separately, the residual alcohol is recovered from the lighter phase, releasing the methylic or ethylic esters for the following phases (Parente, 2003).

\section{Dehydration of Alcohol}

In the case of dehydration of alcohol, the distillation process is very simple and easy to be conducted, once the relative volatility of this mixture is very high. Moreover, the phenomenon known as azeotropy does not take place, which would make complete distillation difficult (Parente, 2003).

\section{Purification of Esters}

The esters should be washed by centrifugation and then dehumidified, resulting in biodiesel as the final product. The biodiesel then needs to be adjusted to the specifications present in the technical regulations established for the use of biodiesel as fuel for engines of the diesel cycle (Parente, 2003).

\section{Distillation of Glycerin}

The purification of raw glycerin is made through vacuum distillation, resulting in a clear and transparent product, commercially known as distilled glycerin (Parente, 2003).

\section{Automation and Control of the Mini-plant of Biodiesel}

In order to accomplish the objective of the study, it is necessary that the mini-plant of biodiesel has sensors, actuators, and controllers. These instruments together constitute what is known as an automated process.

The automation in a productive environment aims to facilitate the processes, using basic components such as sensors, controllers, and actuators. The automated system aims at the optimization of the process, increasing the production rate, precision and quality, including the reduction in costs. (Prudente, 2007)

The automation process consists in the interaction of electrical, electronic, mechanical, and information technology areas. The mechanic area, through the use of machines, can separate raw material into "final" products. The electrical engineering provides the engines and its operations, and the electronic is essential for the control and automation of the production network. The information technology allows the distribution of information to all levels of the industry, through its data bases and communication networks.

The control theory refers to a behavior analysis of the dynamic systems, through which the real behavior 
of an automatic system can be verified. When interacting with automation, it becomes a new concept called mechatronics, which is also known as automation and control.

For implementing the control and automation of the production process of the mini biodiesel plant it is necessary to control the following variables: pressure, flow, temperature, and level. This process is also known as instrumentation.

Table 3

Definition of the Variables to be Controlled

\begin{tabular}{|l|l|}
\hline Concept & Definition \\
\hline Pressure & $\begin{array}{l}\text { Pressure can be defined as the action of a force against a contrary force. It has the nature of a pull evenly } \\
\text { distributed over a level surface inside a closed recipient. }\end{array}$ \\
\hline Flow & $\begin{array}{l}\text { Defined as the quantity of fluids going through the straight section of a duct, by unity of time. This fluid } \\
\text { can be liquid, gas or vapor. }\end{array}$ \\
\hline Temperature & $\begin{array}{l}\text { According to classic physics, temperature quantifies heat, which is a form of energy associated to the } \\
\text { molecule activity of a substance. The higher the molecular agitation, the higher the quantity of heat and } \\
\text { temperature of the substance. }\end{array}$ \\
\hline Level & Determination of the position of an interface between two sides. \\
\hline
\end{tabular}

Note. Source: Bega et al. (2006), Delmée (2006), and Cohn (2006).

Instrumentation is the science that develops and applies techniques of measurement, indication, registration, and control of manufacturing processes, aiming at the optimization and efficiency of these processes.

In order to have control of the process, the instruments must be interconnected, so that it is possible to perform a certain function in the production process.

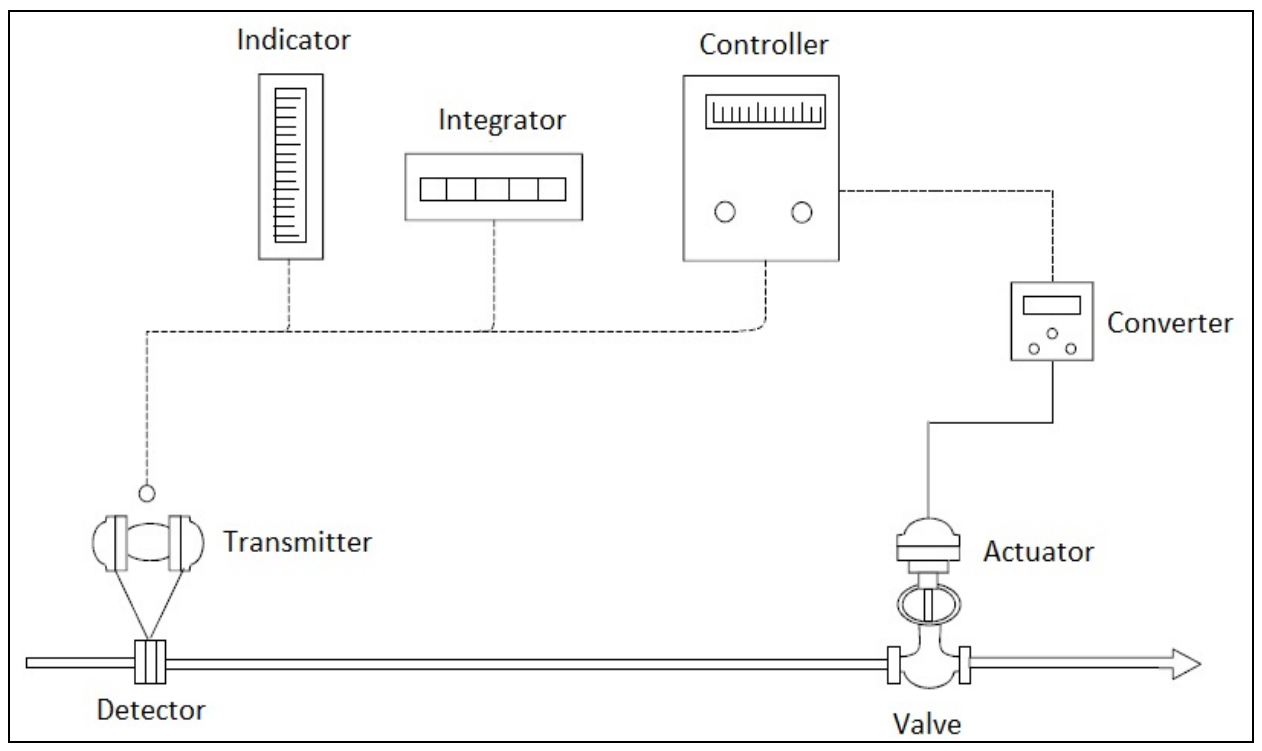

Figure 9. Interconnection of the instruments. Fonte: SENAI, 1999.

According to the norm ISA-S5, each instrument or function programmed will be identified by a group of letters representing its function. Another group of algorithms will indicate the network to which the instrument or function programmed belongs to (Gonçalves, 2003).

The symbols presented in Figures 10 and 11 are used in process and engineering flowcharts. The transmission signs can vary according to Figure 10. 


\begin{tabular}{|l|l|}
\hline $\begin{array}{l}\text { Process fitting, mechanical } \\
\text { connection or supply }\end{array}$ & Capillary tube (full system) \\
\hline Waterworks & \\
\hline Electrical signal & \\
\hline $\begin{array}{l}\text { Pneumatic signal or sign for an } \\
\text { indefinite process diagrams }\end{array}$
\end{tabular}

Figure10. Symbology according to the ABNT Norm (NBR-8190). Source: NBR-8190, 1983.

To represent the instrument and indicate where it is placed, the symbols used are as showed by Figure 11 .

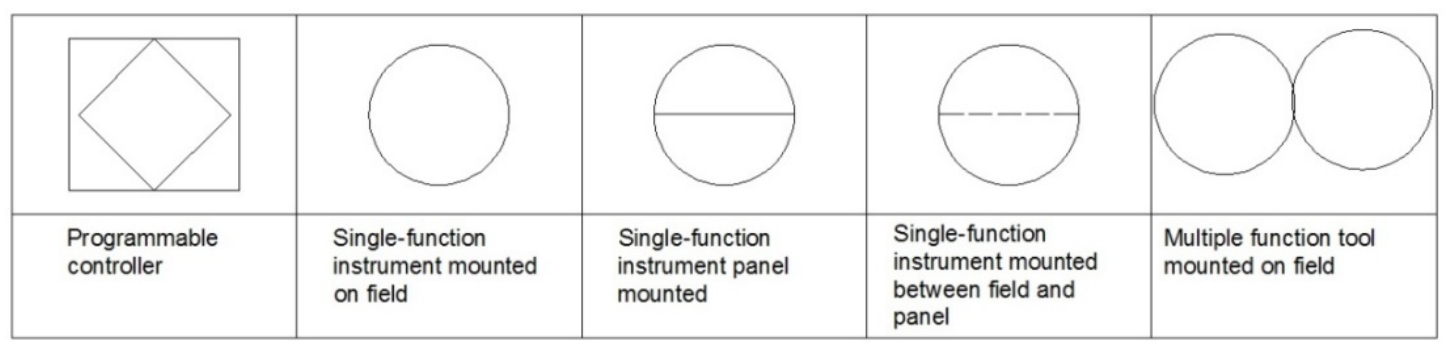

Figure 11. Symbology for instrument. Source: SENAI, 1999.

Each instrument receives a distinct nomenclature, through which it is possible to know its function in the system.

According to Figures 10 and 11, it is possible to identify an instrument as shown in Table 4. According to its tag, this instrument is a controller register of temperature, situated at the network 210 , in the second place, therefore having the label TRC-210-2-A.

Table 4

Identification of the Instrument

\begin{tabular}{|c|c|c|c|c|}
\hline $\mathrm{T}$ & $\mathrm{R} \mathrm{C}$ & 210 & 2 & A \\
\hline Variable & Function & Area of activity & No. of sequence in the network & \\
\hline \multicolumn{2}{|c|}{ Funcional identification } & Identification of network & & 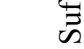 \\
\hline \multicolumn{2}{|c|}{ Identification of instrument } & & & \\
\hline
\end{tabular}

Note. Source: Bega et al., 2006.

The production process of the mini biodiesel plant for this project would not be complete, according to Figure 7. This is due to the fact that there will be no recovery of the methylic or ethylic alcohol. Therefore the process will be performed as shown in Figure 12.

The case study of this project consists in a proposal to automate the production process of a mini biodiesel plant, to be built by the Metropolitan Faculty of Camaçari (FAMEC).

Figure 13 illustrates the automated plant. 


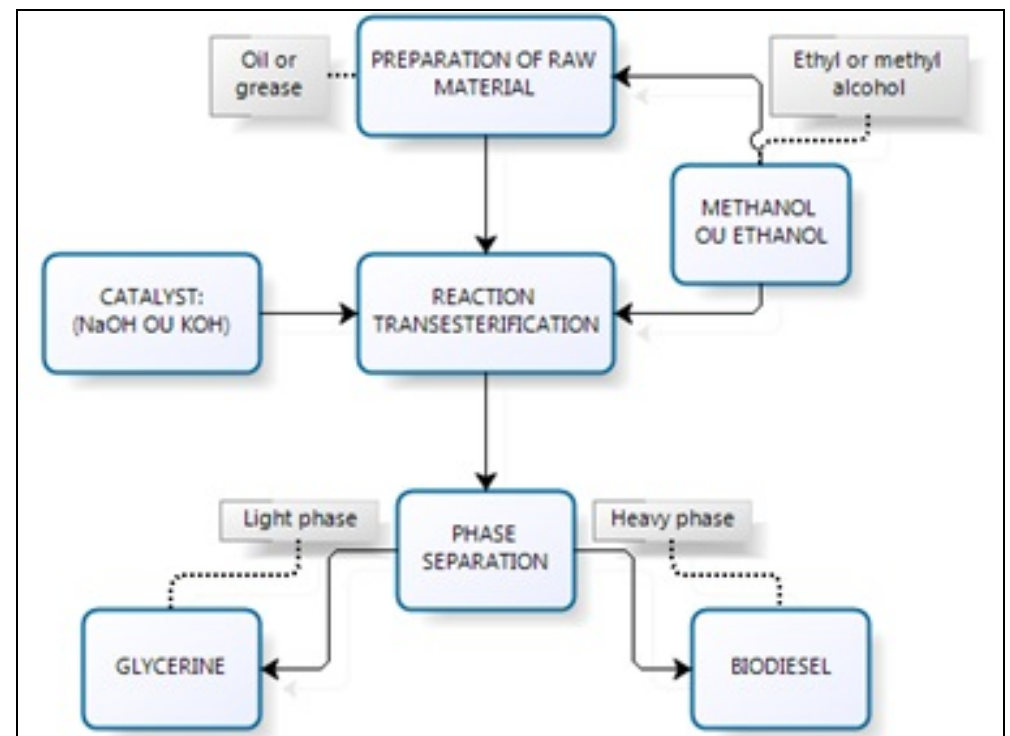

Figure 12. Production process in the mini biodiesel plant at FAMEC. Source: FAMEC, 2012.

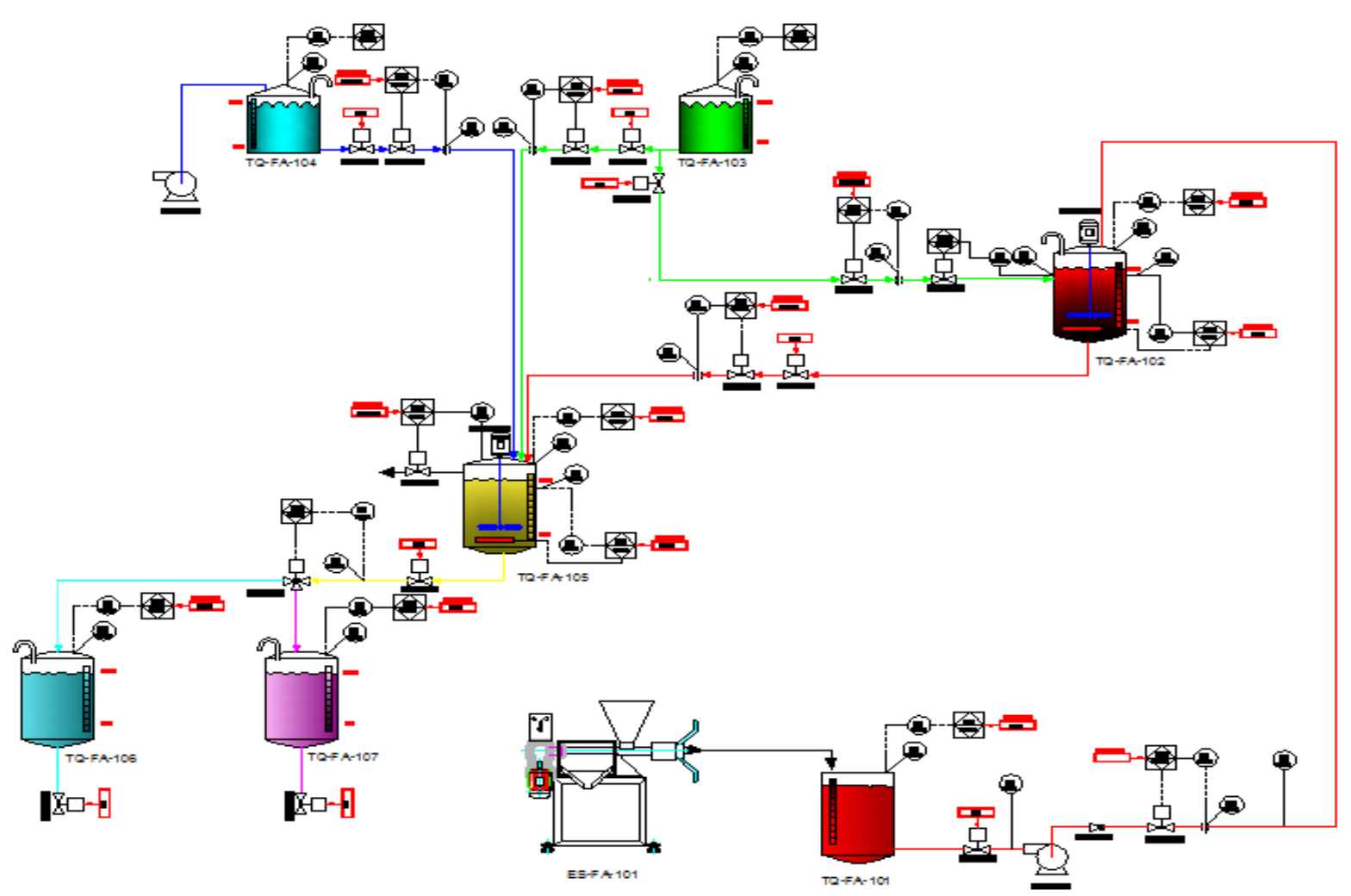

Figure 13. Automation and control project of the mini biodiesel plant-FAMEC. Source: FAMEC-MUB-02-001.

As mentioned in previous paragraphs and references, the automation of the production process occurs in the following phases:

- Preparation of raw material.

In this phase a Mini Press Ecirtec MPE-40TI with the tag ES-FA-101 is used for milling the raw material, which will then be transported to the tank TQ-FA-101. 
- Transposition of milled raw material.

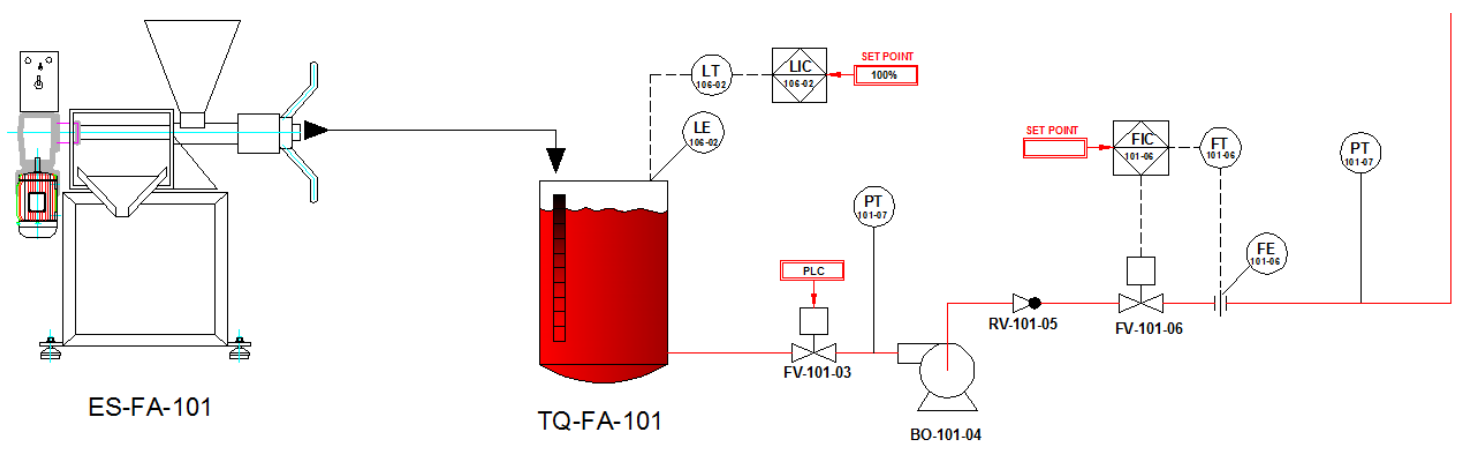

Figure 14. Milling and transportation of raw material. Source: FAMEC-MUB-02-001.

In Figure 14, the transposition of raw material will be made by the pump BO-101-05. After this, other instruments will be responsible for control of the flow (FIC-101-06) and pressure indicator (PI-101-07). The data will be processed by PLC, which will control the speed of the pump-engine through an AC drive.

As in this transport the tank TQ-FA-102 that receives the milled raw material will be at six meters high, a flow retention valve RV-101-07 will be used to avoid the return of the fluid inside the pipes, also avoiding a reverse pressure on the pump and its components.

The tank TQ-FA-101 will also have a level control, so that the process does not start without a minimum pre-determined quantity, avoiding air going into the pump BO-101-04.

Attention should be paid in the choice of this pipe, as there will be internal pressure in the pump and the viscosity of the oleaginous plant. Depending on the material used, the pipe may not support the pressure and leaking can occur.

- Alcohol and sodium hydroxide storage.

To realize the transesterification, alcohol (methylic or ethylic) and sodium hydroxide will need to be added. For that purpose, storage tanks TQ-FA-104 and TQ-FQ-103 will be used. Both will have level control to avoid the process start without the minimum quantity of fluid needed. Will be installing a sighas there is no need to control the internal pressure. The flow control will be predetermined for each type of oleaginous plant used.

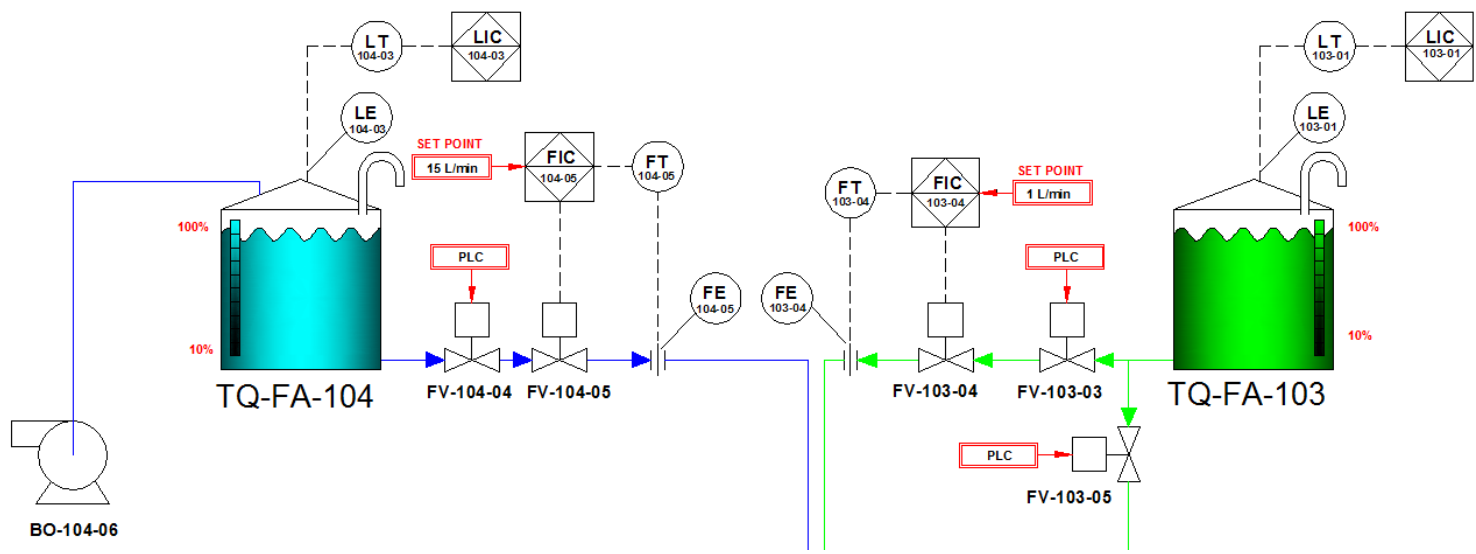

Figure 15. Storage tank for ethanol and soda. Source: FAMEC-MUB-02-001.

In Figure 15, the supply of tank TQ-FA-104 will occur through a pump, since its height is equal or superior to six meters. Therefore, the supply tank will be in the first level, and the transposition of fluids will 
use the force of gravity. To supply the tank TQ-FA-103 it is not necessary to use a pump, as this will have a lower capacity and can be supplied manually with either liquid or solid (block).

- Control of $\mathrm{pH}$.

Aiming at controlling the fluid $\mathrm{pH}$, at this stage there will be no addition of sodium hydroxide in the tank TQ-FA-102 containing the prepared raw material. For such control, a group of interconnected equipment will be used, with distinct functions and objectives, composed by a $\mathrm{pH}$ sensor, a transductor of this sensor, a controller and an indicator of the variable in question. A valve will be controlled by the DIC-103-107 and when the desired $\mathrm{pH}$ is reached, the valve will close. In parallel, the engine MO-102-06 will mix the raw material with the soda. During the pre-established neutralization period, the temperature will be kept at $80{ }^{\circ} \mathrm{C}$, and the fluid will then be transported by gravity to the tank TQ-FA-105 showed in Figure 16.

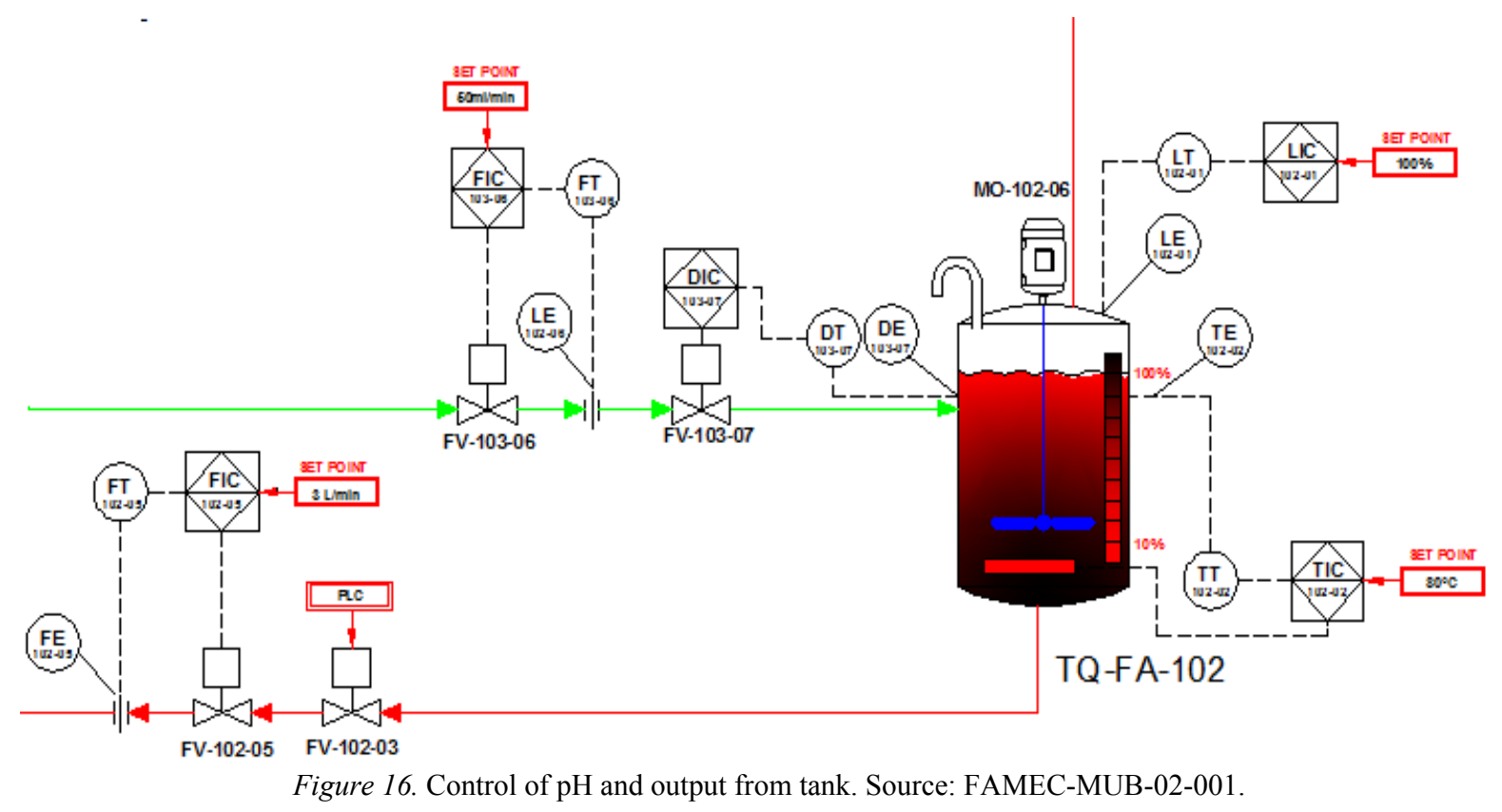

In this phase, the temperature of the oleaginous plant should also be considered in order to choose the pipes. Another important aspect is the diameter, since the process will be performed through gravity from then on.

\section{- Transesterification.}

Besides the addition of soda, in this phase the ethanol will also be added, completing the process of transesterification (see Figure 17). In the same way that in the previous phase, there will be a mixing engine MO-105-06, and in parallel, the temperature will be kept at $100{ }^{\circ} \mathrm{C}$. In this phase a chemical reaction occurs where the triglyceride (oleaginous plant) reacts with the alcohol in the presence of a strong base or acid, and a mixture of fatty acids and glycerol will be produced.

When the ideal temperature and chemical mixture of the elements are reached, 120 minutes are necessary to perform the decantation process. In other words, glycerol and fatty acids will be separated.

- Phase separation.

After decantation is concluded, with the fluids separated by gravity, they will drain. In Figure 18, as the glycerol is denser, it will soon be at the bottom of the tank, which will be directed to the tank TQ-FA-107, until 
the density sensor detects the change of fluids. After this change is noticed, the flux will be directed to the tank TQ-FA-106, through a triple globe valve, separating glycerin.

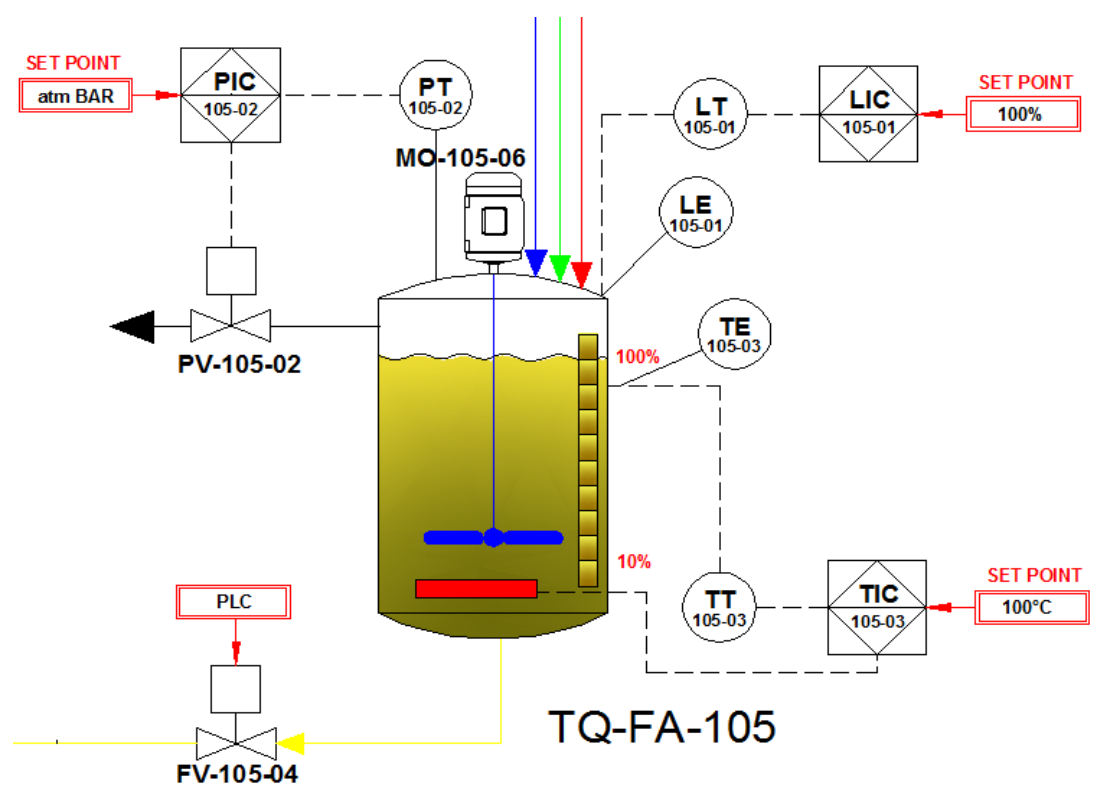

Figure 17. Realization of transesterification. Source: FAMEC-MUB-02-001.

The tanks are equipped with a level controller to determine the end of a production cycle (maximum storage capacity) and also to identify the quantity of biodiesel and glycerin produced.

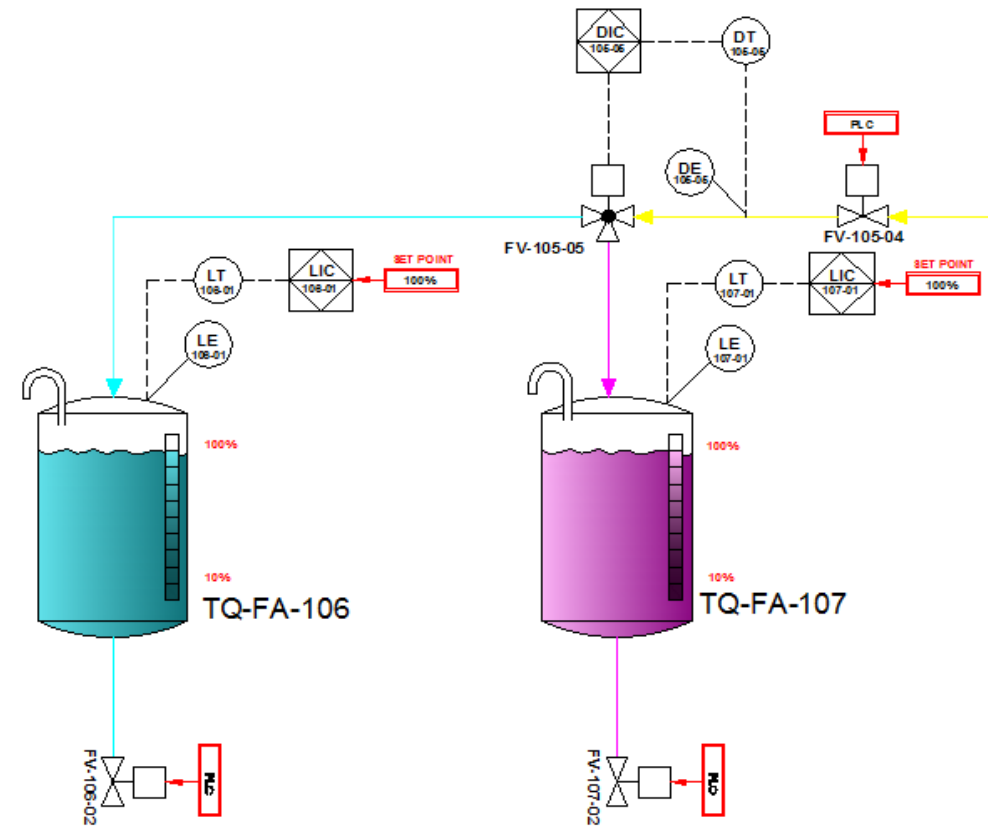

Figure 18. Separation of raw material. Source: FAMEC-MUB-02-001. 


\section{References}

Associação Brasileira de Normas Técnicas. (1983). NBR 8190: Symbology instrumentation (Simbologia de instrumentação). Rio de Janeiro: ABNT.

Atkins, P., \& Jones, L. (2001). From chemistry questioning modern life and environment principles (Principios De Química-Questionando a Vida Moderna e o Meio Ambiente). Porto Alegre: Boockman.

Bega, E. A., Koch, R., \& Finkel, V. S. (2011). Industrial instrumentation (Instrumentação industrial). Rio de Janeiro: Editora Interciência.

Brafman, I. (2009). Econometric model for the projection of the apparent fuel consumption in Brazil-otto and diesel (Modelo econométrico para a projeção do consumo aparente de combustível no Brasil—otto e diesel) (Mestrado Dissertação, Faculdade De Economia E Finanças Ibmec, Rio de Janeiro).

Bueno, O. C., Esperancini, M. S. T., \& Takitane, I. C. (2009). Biodiesel production in Brazil: Socioeconomic and Environmental Aspects (Produção de biodiesel no Brasil: Aspectos socioeconômicos e ambientais). Revista Ceres, 56(4), 507-551.

Chavane, C. G. (1938). Procedure for the transformation of vegetable oils for their uses as fuels. Belgian Patent 422,877, Belgica.

Cohn, P. E. (2006). Analisadores industriais no processo, na área de utilidades, na supervisão da emissão de poluentes e na segurança. São Paulo: Interciência.

Companhia Nacional de Abastecimento (CONAB). (2008). Ethanol as a new universal fuel: Statistical analysis and projection of domestic consumption and export of Brazilian ethanol in the period 2006-2011 (O etanol como um novo combustivel universal: análise estatística e projeção do consumo doméstico e exportação de álcool etílico brasileiro no periodo de 2006 a 2011). Retrieved from http://www.conab.gov.br

D'avila, L. A. (2011). Limits of biodiesel production in Brazil (Limites da produção de biodiesel no Brasil). Proceedings from BIOCOM-4 $4^{\circ}$ simpósio nacional de biocombustiveis. Escola química da UFRJ, LABCOM-Laboratório de Combustíveis e Derivado do Petróleo. Rio de Janeiro.

Delmée, G. J. (2006). Manual flow measurement (Manual de Medição de Vazão). São Paulo: Edgard Blucher LTDA.

Famec. (2012). Pedagogical course design control engineering and automation (Projeto pedagógico do curso de engenharia de controle e automação) (p. 182). Camaçari.

Feltre, R. (2004). Chemistry (Química) (6th ed.). São Paulo: Moderna.

Ferrés, D. H. S. (2010). Competitiveness of biofuels in Brazil: A comparison of the major biofuels-ethanol and biodiesel (Competitividade dos biocombustíveis no Brasil: Uma comparação entre os principais biocombustíveis—etanol e biodiesel) (Mestrado Dissertação, Fundação Getúlio Vargas, Escola de Economia de São Paulo, São Paulo).

Geris, R., Santos, N. A. C., Amaral, B. A., Maia, I. S., Castro, V. D., \& Carvalho, J. R. M. (2007). Soy-biodiesel transesterification reaction for practical organic chemistry (Biodiesel de soja-Reação de transesterificação para aulas práticas de química orgânica). Retrieved from http://www.scielo.br/scielo.php?script=sci_arttext\&pid=S0100-40422007000500053

Gonçalves, M. G. (2003). Monitoring and process control (Monitoramento e controle de processo). Petrobras: Rio de Janeiro.

Grimoni, J. A. B., Udaeta, M. E. M., Baitelo, R. L., \& Burani, G. F. (2006). Comparison of energy production with diesel and biodiesel analyzing all the costs involved (Comparação da produção de energia com diesel e biodiesel analisando todos os custos envueltos). Universidade São Paulo, São Paulo.

Leal, M. R. L. V., \& Leite, R. C. C. O. (2007). Biofuel in Brazil (Biocombustível no Brasil). Novos estudos, 78, 15-21.

Lopes, O. C., \& Maciel, A. J. S. (2006). pat. 0603857-3A. Universidade Estudal de Campinas—São Paulo, Brasil.

Meirelles, F. S. (2003). Biodiesel. Retrieved from http://www. forumdeenergia.com.br/nukleo/pub/biodiesel.pdf

Parente, E. J. S. (2003). Biodiesel: A technological adventure in a funny country (Biodiesel: uma aventura tecnológica num pais engraçado). Fortaleza: Tecbio.

Pétris, G. C., Pereira, L. F. C. A., \& Silva, E. R. P. (2007). Tutorial on alternative energies (Tutorial sobre Energias Alternativas). Retrieved from http://www.telecom.uff.br/pet/petws/downloads/tutoriais/energias/TutPetTeleFontesAlts.pdf

Prudente, F. (2007). Industrial automation-PLC-theory and applications (Automação industrial-PLC-Teoria e aplicações). São Paulo: Ltc,.

Rampin, M. A., Bronzel, J. L., \& Dabdoub, M. J. (2009). Biodiesel: A critical overview of the current status and perspectives in academia and industry (Biodiesel: visão crítica do status atual e perspectivas na academia e na indústria). Química Nova, 32(3), 776-792.

Santori, G., Di Nicola, G., Moglie, M., \& Polonara, F. (2011). A review analyzing the industrial biodiesel production practice starting from vegetable oil refining. Applied Energy, 92, 109-132. 
Schechtman, R., \& Pires, A. (2012). Analysis of fuel prices and international policies to promote biofuels (Análise de preços de combustíveis e de políticas internacionais para promoção de biocombustiveis). Retrieved from http://www.unica.com.br/downloads/estudosmatrizenergetica/pdf/Matriz_Internacional_Pires7.pdf

Serviço Nacional de Aprendizagem Industrial (SENAI). (1999). Basic instrumentation-Pressure and level (Instrumentação básica-Pressão e nivel). Espírito Santo: SENAI.

Santacesaria, E., Vicente, G. M., Di Serio, M., \& Tesser, R. (2012). Main technologies in biodiesel production: State of the art and future challenges. Catalysis Today, 195, 2-13.

Urioste, D. (2004). Production of biodiesel by enzymatic catalysis babassu oil with short chain alcohols (Produção de biodiesel por catálise enzimática do óleo de babaçu com álcoois de cadeia curta) (Mestrado Dissertação, Faculdade de Engenharia Química de Lorena, Lorena). 